\title{
Teacher professional development through lesson study in secondary schools
}

\begin{abstract}
Lesson Study (LS) is a professional learning strategy which originated from Japan and practiced extensively throughout Japan. It has captured the attention of the professional learning communities in Malaysia and is seen as an innovative strategy for teacher professional development (TPD). The purpose of this study was to explore secondary school English Language (EL) teachersôlearning experiences as they engaged in LS as well as to explore LS as a strategy for teacher professional development at secondary schools. The research methodology adopted was a qualitative case study of a single site and involved four participants. Each participant completed two LS cycles in three months. Data was collected through classroom observations and document analysis. Analytic induction was used to analyze the data. The findings of the study affirmed the literature on the importance of peer collaboration and feedback, and improving instructional practices particularly teachersô professional knowledge. However, time-constraints, extra workload, and minimal school management support were some constraints noted during the implementation of LS in schools. Lesson study provides an alternative strategy for the in-service teachers to enhance their professional development as well as encourages the teachers to solve their studentsô learning problems in actual classrooms collaboratively.
\end{abstract}

Keyword: Lesson study; Professional development community; Professional learning communities; Teacher professional development 